\title{
UJI AKTIVITAS ANTIOKSIDAN EKSTRAK BAWANG HITAM (BLACK GARLIC) DENGAN VARIASI LAMA PEMANASAN
}

\section{ANTIOXIDANT ACTIVITY OF BLACK GARLIC EXTRACT WITH VARIATIONS OF THE HEATING TIME}

\author{
Eva Agustina, Funsu Andiarna*, Irul Hidayati \\ Universitas Islam Negeri Sunan Ampel, Jl. A.Yani 117, Surabaya \\ *Corresponding author: funsu_andiarna@uinsby.ac.id
}

Naskah Diterima: 31 Juli 2019; Direvisi: 30 November 2020; Disetujui: 3 April 2020

\begin{abstract}
Abstrak
Senyawa radikal dalam tubuh sangat reaktif terhadap sel-sel, sehingga dapat menyebabkan berbagai penyakit. Senyawa yang mampu menangkal radikal bebas disebut antioksidan. Bawang hitam diketahui mengandung senyawa aktif fenolik dan turunannya sehingga dapat digunakan sebagai antioksidan. Penelitian tentang penggunaan bawang hitam sebagai antioksidan ini bertujuan untuk mengetahui perbedaan lama pemanasan $(15,25$, dan 35 hari) terhadap aktivitas antioksidan pada ekstrak bawang hitam. Bawang hitam diperoleh dengan cara memanaskan bawang putih selama 15, 25, dan 35 hari. Bawang hitam selanjutnya diekstraksi dengan pelarut metanol dengan metode maserasi. Filtrat hasil ekstraksi dipekatkan dengan rotary evaporator untuk mendapatkan ekstrak bawang hitam. Ekstrak bawang hitam diuji fitokimia untuk mengetahui kandungan senyawa aktif. Aktivitas antioksidan ekstrak bawang hitam ditentukan dengan metode penangkalan radikal 2,2diphenyl-1-picrylhydrazyl (DPPH). Hasilnya menunjukkan ekstrak bawang hitam memiliki aktivitas antioksidan yang sangat kuat dengan nilai IC50 masing-masing 15 hari yaitu 2,41 $\mu \mathrm{g} / \mathrm{mL}$; 25 hari yaitu $2,93 \mu \mathrm{g} / \mathrm{mL} ; 35$ hari yaitu $2,27 \mu \mathrm{g} / \mathrm{mL}$. Nilai IC $50<10 \mu \mathrm{g} / \mathrm{mL}$ menunjukkan bahwa ekstrak bawang hitam dengan lama pemanasan 15, 25, dan 35 hari memiliki potensi antioksidan yang sangat kuat. Lama pemanasan yang paling optimum dalam penangkalan radikal bebas adalah ekstrak bawang hitam dalam lama pemanasan 35 hari, karena banyak terdapat kandungan senyawa flavonoid, tanin, sterol, dan saponin.
\end{abstract}

Kata kunci: Antioksidan; Bawang hitam; Fitokimia; Maserasi

\begin{abstract}
Radical compounds in the body are very reactive to cells that can cause various diseases. Compounds that can ward off free radicals are called antioxidants. Black garlic is known to contain phenolic activecompounds and their derivatives so that they can be used as antioxidants. Research on the use of black garlic as an antioxidant aims to determine the difference in heating time $(15,25$, and 35 days) on the antioxidant activity of black garlic extract. Black garlic was obtained by heating the garlic for 15, 25, and 35 days. The black garlic is then extracted with methanol solvent by maceration method. The extracted filtrate was concentrated with a rotary evaporator to obtain the black garlic extract. Black garlic extract was tested for phytochemistry to determine the content of active compounds. The antioxidant activity of black garlic extract was determined by the radical deterrence method 2,2-diphenyl-1-picrylhydrazyl (DPPH). The results showed that the onion extract had a very strong antioxidant activity with an $I_{50}$ value of 15 days each of $2.41 \mu \mathrm{g} / \mathrm{mL}$; 25 days which is $2.93 \mu \mathrm{g} / \mathrm{mL}$; 35 days which is $2.27 \mu \mathrm{g} / \mathrm{mL}$. $I C_{50}$ values $<10 \mu \mathrm{g} / \mathrm{mL}$ indicate that the black garlic extract with a heating time of 15, 25, and 35 days has a very strong antioxidant potential. The most optimum heating time in deterring free radicals is black garlic extract within 35 days of heating because there are many compounds containing flavonoids, tannins, sterols, and saponins.
\end{abstract}

Keywords: Antioxidant; Black garlic; Maceration; Phytochemicals

Permalink/DOI: http://dx.doi.org/10.15408/kauniyah.v13i1.12114 


\section{PENDAHULUAN}

Penyakit kanker merupakan salah satu penyebab utama kematian di seluruh dunia. Pada tahun 2012, sekitar 8,2 juta kematian disebabkan oleh kanker. Kanker paru, hati, perut, kolorektal, dan payudara adalah penyebab terbesar kematian akibat kanker setiap tahunnya (Kementerian Kesehatan RI, 2015). Pada tahun 2016 diketahui untuk penderita kanker serviks terdapat 73.453 jiwa dan kanker payudara 4.030 jiwa. Penyakit kanker disebabkan oleh senyawa radikal bebas yang tidak terkendali dalam sel tubuh. Sumber pembentuk radikal bebas dalam sel tubuh antara lain asap rokok, makanan yang digoreng, paparan sinar matahari berlebih, asap kendaraan bermotor, obat-obat tertentu, racun, dan polusi udara. Penyakit lain yang dapat disebabkan radikal bebas selain kanker adalah arteriosklerosis dan penuaan dini (Ulfa \& Hidayat, 2007). Secara garis besar, radikal bebas berperan penting pada kerusakan jaringan dan proses patologi dalam organisme hidup (Velázquez, Tournier, Mordujovich de Buschiazzo, Saavedra, \& Schinella, 2003). Senyawa yang mampu menunda, memperlambat, atau menghambat reaksi oksidasi akibat radikal bebas dinamakan senyawa antioksidan (Halliwell \& Gutteridge, 2015).

Beberapa studi epidemiologi menunjukkan bahwa peningkatan konsumsi antioksidan alami yang terdapat pada buah, sayur-sayuran, dan berbagai tanaman mempunyai manfaat besar terhadap kesehatan (Ghiselli, Nardini, Baldi, \& Scaccini, 1998). Hal ini karena potensi antioksidan yang terkandung dalam buah, sayur-sayuran dan berbagai tanaman tersebut seperti karoten, flavonoid, dan komponen fenolik lainnya (Teow et al., 2007).

Bawang putih (Allium sativum) telah digunakan di seluruh dunia sebagai obat tradisional selama lebih dari 4.000 tahun untuk mengobati beberapa gangguan seperti arthritis, diabetes, dan penyakit menular (flu, malaria, dan TBC). Selain itu, bawang putih juga bermanfaat untuk mengurangi tekanan darah, menurunkan kolesterol, mencegah serangan jantung dan kanker, serta menghambat pertumbuhan mikroba (Wang et al., 2010). Banyak studi terbaru menunjukkan efek farmakologis dari bawang putih, yaitu sebagai antibakteri, antijamur, hipolipidemik, hipoglikemik, antirombotik, antioksidan, dan antikanker (Song \& Milner, 2001).

Bawang putih mengandung sekitar $63 \%$ air, 28\% karbohidrat (fruktans), 2,3\% asam komponen organosulfur, 2\% protein (alliinase), 1,2\% asam amino bebas (arginin), dan $1,5 \%$ serat. Bawang putih mengandung tinggi jumlah senyawa g-glutamylcysteines. Senyawa ini bisa dihidrolisis dan teroksidasi untuk membentuk alliin yang terakumulasi selama penyimpanan bawang putih pada suhu dingin. Pada pengolahan bawang putih seperti pemotongan atau menghancurkan maka alliinase akan mengkonversi alliin menjadi allicin (Kimura et al., 2017). Di Indonesia dikenal ada 3 (tiga) kelompok varietas bawang putih yaitu varietas lumbu hijau, varietas lumbu kuning, dan varietas lumbu putih (Rukmana, 1995), akan tetapi bawang putih dengan tingkat produksi tertinggi adalah pada varietas lumbun hijau, dengan rata-rata produksi 7 ton per hektar (Sengin, 1992).

Penggunaan bawang putih sebagai bahan obat kurang diminati, karena adanya senyawa allicin yang memberi ciri khas bau pada bawang putih dan menimbulkan rasa getir. Oleh karena itu, dalam beberapa tahun terakhir berbagai metode pengolahan seperti perlakuan pemanasan pada bawang putih telah dilakukan untuk menghilangkan bau dan rasa pada bawang putih. Metode pemanasan ini dipilih karena dalam metode pengolahannya relatif mudah. Ketika bawang putih mengalami perlakuan panas, berbagai perubahan fisikokimia terjadi seperti perubahan bau, rasa, warna, dan kandungan gizi. Perlakuan panas dan pemanasan pada bawang putih menyebabkan terjadinya reaksi pencokelatan non-enzimatik yang terkait dengan pembentukan senyawa dengan sifat antioksidan yang kuat. Proses pemanasan dapat menghambat aktivitas enzim alliinase pada suhu di atas $60{ }^{\circ} \mathrm{C}$ (enzim alliinase inaktif) (Hernawan \& Setyawan, 2003).

Di China, bawang putih dikembangkan menjadi bawang hitam dengan proses pemanasan sehingga memiliki aktivitas antioksidan yang kuat baik in vivo maupun in vitro. Aktivitas antioksidan dari bawang hitam dapat dipengaruhi oleh metode pengolahan dan 
kondisi bawang putih dengan mengontrol suhu dan kadar air. Produk bawang hitam memiliki kandungan tinggi pada polisakarida, mengurangi gula, protein, senyawa fenolik, dan senyawa sulfur. Jumlah polifenol meningkat enam kali lipat dalam kupasan bawang hitam. Selain itu, total polifenol dan jumlah flavonoid bawang hitam meningkat secara signifikan selama proses pemanasan (Lu, Li, Qiao, Qiu, \& Liu, 2017). Menurut Sasaki, Lu, Machiya, Tanahashi, dan Hamada (2007) unsur kimia yang terkandung dalam bawang hitam mengalami peningkatan yang sangat signifikan. Karbohidrat pada bawang putih segar sebesar $28,7 \%$ dan meningkat sebesar $47,0 \%$ pada bawang hitam. Unsur lainnya juga terjadi peningkatan, akan tetapi tidak terjadi banyak perubahan, misalnya protein pada bawang putih $8,4 \%$ dan pada bawang putih $9,1 \%$. Lemak pada bawang putih segar $0,1 \%$ sedangkan pada bawang hitam $0,3 \%$.

Di Indonesia, sampai saat ini belum dilakukan penelitian tentang proses pemanasan bawang putih untuk dibuat menjadi bawang hitam. Beberapa penelitian yang telah dilakukan mengadopsi suhu dan lama pemanasan dari penelitian di Negara Jepang dan Cina, namun hal inipun tidak dijelaskan proses pemanasan secara detail. Jenis bawang putih di Indonesia akan berbeda dengan bawang putih di negara lain, oleh karena perbedaan pengaruh geografis. Menurut beberapa penelitian proses pemanasan bawang putih menjadi bawang hitam menggunakan suhu antara $40-90{ }^{\circ} \mathrm{C}$ dalam rentang 5-45 hari (Angeles, Jesus, Rafael, \& Tania, 2016). Kelembapan bawang hitam menurun secara teratur sampai hari ke-45, sedangkan intensitas pencokelatan, total flavonoid, fenolik dan kapasitas antioksidan perlu dilakukan penelitian lebih lanjut untuk mengetahui lama optimum (Bae, Cho, Won, Lee, \& Park, 2014). Proses penghitaman bawang putih menjadi bawang hitam disebabkan reaksi Maillard. Reaksi Maillard terjadi dalam tiga tahap, pada tahap awal pemanasan terjadi kondensasi gugus gula dan gugus amina, warna yang dihasilkan belum terlalu cokelat. Tahap dua menghasilkan warna cokelat dan tahap akhir reaksi Maillard menghasilkan warna hitam, karena karamelisasi dan pembentukan polifenol. Pemanasan pada bawang hitam menghasilkan senyawa $S$-Allyl cystein tetrahydro-B-Carbolines yang berasal dari perubahan senyawa allicin bawang putih. Menurut penelitian Amagase (2006) yang menyatakan bahwa kandungan senyawa aktif dari bawang hitam lebih melimpah dibandingkan dengan kandungan yang ada pada bawang putih. Proses pemanasan menginduksi peningkatan SAC (S-allyl cysteine) sebesar enam kali lipat daripada bawang putih. Penelitian Sasaki et al. (2007) juga menjelaskan bahwa SAC pada bawang hitam meningkat secara drastis mencapai 194,3 $\mu \mathrm{g} / \mathrm{g}$ selama 40 hari pemanasan (SAC pada bawang putih segar $23,7 \mu \mathrm{g} / \mathrm{g}$ ). Pengaturan lama pemanasan dapat memengaruhi kualitas dari bawang hitam yang dihasilkan. Oleh karena itu pada penelitian ini perlu dilakukan perbedaan lama pemanasan $(15,25$, dan 35 hari) terhadap aktivitas antioksidan pada ekstrak bawang hitam. Variasi lama pemanasan bertujuan untuk melihat berapa lama lama yang efektif dalam proses pembuatan bawang hitam sehingga diperoleh kandungan senyawa aktif dan memiliki aktivitas antioksidan yang kuat.

\section{MATERIAL DAN METODE}

Metode penelitian adalah eksperimen dengan perlakuan lama penyimpanan atau pemanasan bawang putih saat pembuatan bawang putih hitam $(15,25$, dan 35 hari). Bawang putih digunakan sebagai bahan utama dalam pembuatan bawang hitam. Bawang putih sebanyak $1 \mathrm{~kg}$ dipanaskan dalam oven dengan suhu $70{ }^{\circ} \mathrm{C}$ dan didiamkan selama 15 , 25, dan 35 hari. Hasil dari pemanasan diperoleh bawang hitam. Setelah itu dilakukan ekstraksi dengan metode maserasi. Hasil ekstrak bawang hitam dilakukan uji fitokimia untuk melihat kandungan senyawa aktif dan aktivitas antioksidan.

\section{Ekstraksi Bawang Hitam}

Bawang hitam sebanyak $100 \mathrm{~g}$ dihaluskan hingga diperoleh serbuk bawang hitam. Serbuk bawang hitam diekstraksi dengan metode maserasi dan metanol $1.000 \mathrm{~L}$ sebagai pelarutnya. Hasil ekstraksi kemudian disaring. Residu hasil filtrasi di remaserasi lagi dengan tujuan semua senyawa aktif dapat 
terekstrak semua kepelarut. Filtrat dikumpulkan dan di rotary evaporator dalam suhu kamar selama 24 jam untuk menguapkan pelarut, sehingga diperoleh ekstrak bawang hitam (Chen, Kao, Tseng, Chang, \& Hsu, 2014).

\section{Uji Fitokimia Ekstrak Bawang Hitam}

Uji fitokimia dilakukan untuk mengidentifikasi senyawa aktif yang terkandung dalam bawang hitam secara kualitatif. Senyawa aktif yang diuji yaitu alkaloid, tanin, sterol, saponin, dan flavonoid. Uji fitokimia mengacu pada penelitian yang dilakukan oleh Marliana, Suryanti, dan Suyono (2005).

Uji alkaloid dilakukan dengan menggunakan uji Wagner yaitu ekstrak bawang hitam $3 \mathrm{~mL}$ diletakkan pada cawan porselen ditambahkan $5 \mathrm{~mL} \quad \mathrm{HCl} \quad 2 \quad \mathrm{M}$ kemudian diaduk dan didinginkan pada suhu ruangan. Setelah sampel dingin, ditambahkan $0,5 \mathrm{~g} \mathrm{NaCl}$ kemudian diaduk dan disaring. Filtrat yang diperoleh ditambahkan $\mathrm{HCl} 2 \mathrm{M}$ sebanyak 3 tetes dan pereaksi Wagner sebanyak 5 tetes. Jika terbentuk endapan, menunjukkan adanya alkaloid.

Uji tanin dilakukan dengan mengambil ekstrak bawang hitam sebanyak $3 \mathrm{~mL}$ kemudian diekstraksi dengan akuades panas dan selanjutnya didinginkan. Setelah dingin ditambahkan 5 tetes $\mathrm{NaCl} 10 \%$ kemudian disaring. Filtrat yang dihasilkan ditambahkan $\mathrm{FeCl}_{3}$ 5\%. Adanya tanin ditunjukkan oleh endapan berwarna cokelat tua yang terbentuk.

Uji saponin dilakukan dengan menggunakan metode Forth. Sampel ekstrak bawang hitam $2 \mathrm{~mL}$ dimasukkan dalam tabung reaksi ditambahkan $10 \mathrm{~mL}$ akuades dan dikocok selama 30 detik. Apabila terdapat busa yang tidak hilang selama 30 detik menunjukkan adanya saponin.

Uji sterol dilakukan dengan metode Salkowski. Ekstrak bawang hitam dilarutkan dalam kloroform, kemudian disaring dan filtratnya digunakan untuk pengujian. Larutan ditambahkan beberapa tetes asam sulfat pekat dan diamati perubahan warnanya. Apabila terbentuk warna merah di lapisan bawah maka mengandung sterol dan apabila terbentuk warna kuning keemasan menunjukkan adanya triterpenoid.

Uji flavonoid dilakukan dengan metode Bate Smith-Metchalf. Ekstrak bawang hitam sebanyak $3 \mathrm{~mL}$ diuapkan, kemudian dicuci dengan heksana sampai jernih. Residu dilarutkan dalam $20 \mathrm{~mL}$ etanol dan selanjutnya disaring. Filtrat ditambahkan $0,5 \mathrm{~mL} \mathrm{HCl}$ pekat, kemudian dipanaskan dengan panangas air. Jika terjadi perubahan warna merah, menunjukkan hasil yang positif.

\section{Uji Antioksidan}

Metode pengujian aktivitas antioksidan dengan metode 2,2-diphenyl-1-picrylhydrazyl (DPPH) ini adalah pengukuran aktivitas antioksidan secara kuantitatif dengan mengeplotkan antara konsentrasi dan persen aktivitas antioksidan. Pengukuran penangkapan radikal DPPH oleh suatu senyawa yang mempunyai aktivitas antioksidan dengan menggunakan spektrofotometer UV-Vis sehingga dengan demikian akan diketahui nilai aktivitas peredaman radikal bebas yang dinyatakan dengan nilai inhibitory concentration (IC) 50. Nilai $\mathrm{IC}_{50}$ didefinisikan sebagai besarnya konsentrasi senyawa uji yang dapat meredam $50 \%$ radikal bebas. Semakin kecil nilai $\mathrm{IC}_{50}$ maka aktivitas peredaman radikal bebas semakin tinggi.

Tabel 1. Tingkat kekuatan aktivitas antioksidan dengan metode 2,2-diphenyl-1-picrylhydrazyl (DPPH)

\begin{tabular}{cc}
\hline Intensitas Kekuatan Aktivitas & Nilai IC 50 \\
\hline Sangat kuat & $<50 \mu \mathrm{g} / \mathrm{mL}$ \\
Kuat & $50-100 \mu \mathrm{g} / \mathrm{mL}$ \\
Sedang & $101-150 \mu \mathrm{g} / \mathrm{mL}$ \\
Lemah & $>150 \mu \mathrm{g} / \mathrm{mL}$ \\
\hline
\end{tabular}

Uji Aktivitas antioksidan dengan mencari terlebih dahulu persen inhibisi. Persen inhibisi ditentukan dengan persamaan: \% inhibisi $=$ abs kontrol - abs sampel $/$ abs kontrol $\mathrm{x} 100 \%$. Keterangan: absorbansi kontrol $=$ absorbansi larutan kontrol pada panjang gelombang $517 \mathrm{~nm}$; absorbansi sampel = 
absorbansi larutan uji atau larutan pembanding pada panjang gelombang $517 \mathrm{~nm}$.

Data persen inhibisi radikal bebas dibuat kurva regresi antara persen penangkal radikal bebas sumbu y terhadap konsentrasi larutan uji sumbu x. Dari persamaan regresi linier ditentukan nilai $\mathrm{IC}_{50}$ yaitu konsentrasi inhibisi larutan uji yang mampu menangkal 50\% radikal bebas. Tingkat kekuatan aktivitas antioksidan dari suatu ekstrak dengan metode DPPH dapat dilihat pada Tabel 1.

\section{HASIL}

Proses pembuatan bawang putih menjadi bawang hitam dilakukan pada suhu $70{ }^{\circ} \mathrm{C}$ dengan variasi lama pemanasan. Hasil pengamatan terhadap perbedaan kondisi bawang setelah pemanasan 15,25 , dan 35 hari dapat dilihat pada Tabel 2. Karakteristik berupa warna dan tekstur bawang hitam dapat dilihat pada Gambar 1.

Tabel 2. Karakteristik bawang hitam berdasarkan perbedaan lama pemanasan

\begin{tabular}{llll}
\hline \multirow{2}{*}{ Karakteristik } & \multicolumn{3}{c}{ Lama pemanasan (hari) } \\
\cline { 2 - 4 } & \multicolumn{1}{c}{15} & \multicolumn{1}{c}{25} & \multicolumn{1}{c}{35} \\
\hline Warna & Cokelat tua & Hitam sebagian & Hitam secara menyeluruh \\
Aroma & Agak menyengat & Tidak menyengat & Harum bau bawang \\
Tekstur & Agak keras & Keras & Keras \\
\hline
\end{tabular}
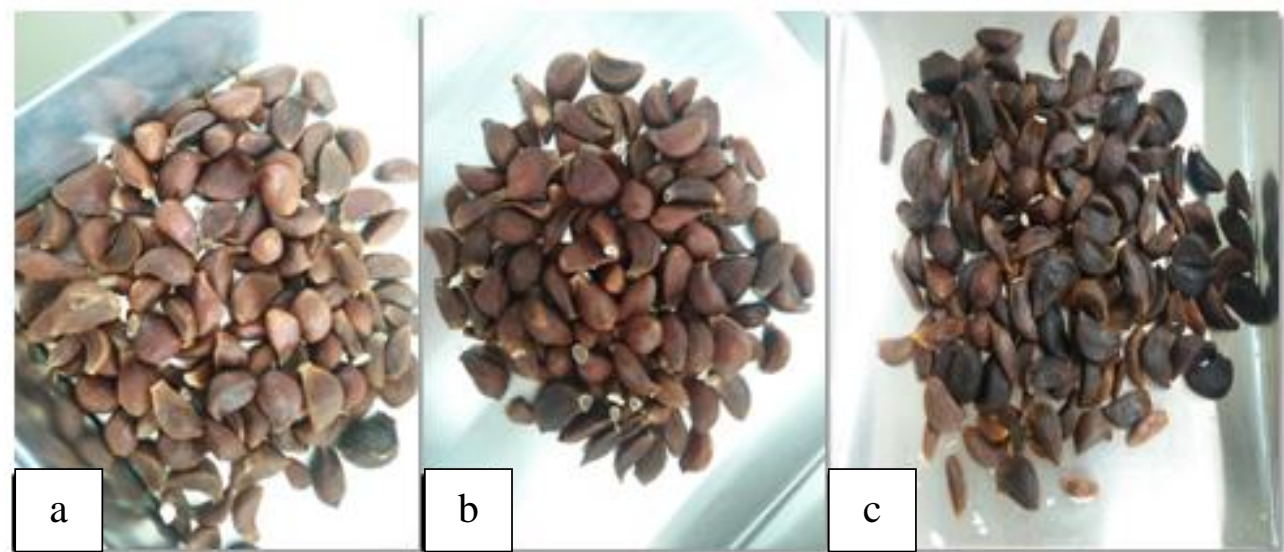

Gambar 1. Karakteristik bawang hitam setelah pemanasan 15 hari (a), 25 hari (b), 35 hari (c)

Tabel 3. Uji fitokimia ekstrak bawang hitam hasil beberapa lama pemanasan

\begin{tabular}{|c|c|c|c|c|}
\hline \multirow{2}{*}{ Senyawa aktif } & \multicolumn{4}{|c|}{ Lama pemanasan (hari) } \\
\hline & Kontrol (0) & 15 & 25 & 35 \\
\hline Alkaloid & $\stackrel{+}{+}$ & $\begin{array}{c}- \\
\text { Tidak ada endapan }\end{array}$ & $\begin{array}{c}- \\
\text { Tidak ada endapan }\end{array}$ & $\begin{array}{c}- \\
\text { Tidak ada endapan }\end{array}$ \\
\hline Tanin & $\begin{array}{c}+ \\
\text { Cokelat muda }\end{array}$ & $\begin{array}{c}++ \\
\text { Cokelat agak tua }\end{array}$ & $\begin{array}{c}+ \\
\text { Cokelat agak tua }\end{array}$ & $\begin{array}{c}++ \\
\text { Cokelat agak tua }\end{array}$ \\
\hline Saponin & $\begin{array}{c}- \\
\text { Tidak ada busa }\end{array}$ & $\begin{array}{c}+ \\
\text { Sedikit busa }\end{array}$ & $\begin{array}{c}+ \\
\text { Sedikit busa }\end{array}$ & $\begin{array}{c}+ \\
\text { Sedikit busa }\end{array}$ \\
\hline Sterol & $\begin{array}{c}- \\
\text { Tidak ada } \\
\text { perubahan }\end{array}$ & $\stackrel{+}{{ }_{\text {Kuning muda }}}$ & $\stackrel{+}{{ }_{\text {Kuning muda }}}$ & $\stackrel{+}{\text { Kuning muda }}$ \\
\hline Flavonoid & $\begin{array}{c}+ \\
\text { Merah }\end{array}$ & $\begin{array}{c}++ \\
\text { Merah tua }\end{array}$ & $\begin{array}{c}+ \\
\text { Merah }\end{array}$ & $\begin{array}{c}+++ \\
\text { Merah bata }\end{array}$ \\
\hline
\end{tabular}

\section{Keterangan :}

Tanda $(-)=$ tidak ada kandungan senyawa aktif

Tanda $(+)=$ ada kandungan senyawa aktif dalam jumlah sedikit

Tanda $(++)=$ ada kandungan senyawa aktif dalam jumlah sedang

Tanda $(+++)=$ ada kandungan senyawa aktif dalam jumlah banyak 
Uji kualitatif kandungan senyawa aktif ekstrak bawang hitam dilakukan dengan uji fitokimia. Berdasarkan uji fitokimia kandungan ekstrak bawang hitam baik pada hari ke 15, 25, dan 35 negatif mengandung alkoloid dan positif mengandung tanin, saponin, sterol dan flavonoid. Kadar masingmasing senyawa aktif dari setiap lama pemanasan ekstrak berbeda-beda hal ini dapat dilihat pada Tabel 3 .

Aktivitas antioksidan ekstrak bawang hitam diperoleh dari pengukuran absorbansi dengan alat spektrofotometer UV-VIS dengan perhitungan. Data absorbansi digunakan untuk menghitung persen inhibisi masing-masing konsentrasi ekstrak bawang hitam pada lama pemanasan 15, 25, dan 35 hari. Hasil perhitungan dapat dilihat pada Tabel 4.

Data absorbansi dan konsentrasi digunakan untuk mencari nilai IC50. Nilai IC $_{50}$ menentukan aktivitas antioksidan suatu ekstrak. Persamaan regresi linier untuk ekstrak bawang hitam dengan lama pemanasan 15 hari yaitu y $=17,46 x-7,882$; ekstrak bawang hitam dengan lama pemanasan 25 hari yaitu $\mathrm{y}=$ 16,26x-2,415 dan ekstrak bawang hitam dengan lama pemanasan 35 hari yaitu $\mathrm{y}=$ $21,24 x-1,751$. Koefisien y pada persamaan ini sebagai $50 \%$ penangkalan radikal bebas, sedangkan koefisien x merupakan nilai IC50. Nilai $\mathrm{x}$ yang didapat merupakan konsentrasi yang diperlukan untuk dapat meredam 50\% aktivitas radikal DPPH. Grafik bagan nilai $\mathrm{IC}_{50}$ pada bawang putih dan ekstrak bawang hitam ditunjukkan pada Gambar 2. Hasil dari nilai $\mathrm{IC}_{50}$ bawang hitam dengan lama pemanasan 15 hari 2,41 ppm; 25 hari 2,93 ppm; dan 35 hari $2,27 \mathrm{ppm}$. Semua bawang hitam dapat dikatakan memiliki aktivitas antioksidan yang baik karena nilai $\mathrm{IC}_{50}<10 \mathrm{ppm}$. Selain itu nilai $\mathrm{IC}_{50}$ bawang hitam secara keseluruhan lebih rendah daripada nilai $\mathrm{IC}_{50}$ bawang putih yakni sebesar 10,61 ppm.

Tabel 4. Hasil uji aktivitas antioksidan dari bawang hitam hasil beberapa lama pemanasan menggunakan metode 2,2-diphenyl-1-picrylhydrazyl (DPPH)

\begin{tabular}{cccc}
\hline Sampel & Konsentrasi & Absorbansi & \%Inhibisi \\
\hline DPPH & $20 \mathrm{ppm}$ & 0,942 & - \\
\hline \multirow{2}{*}{15 hari } & $40 \mathrm{ppm}$ & 0,571 & 39,437 \\
pemanasan & $60 \mathrm{ppm}$ & 0,485 & 48,514 \\
& $80 \mathrm{ppm}$ & 0,422 & 55,202 \\
\hline \multirow{2}{*}{25 hari } & $40 \mathrm{ppm}$ & 0,483 & 48,779 \\
pemanasan & $60 \mathrm{ppm}$ & 0,465 & 50,637 \\
& $80 \mathrm{ppm}$ & 0,437 & 53,609 \\
\hline \multirow{2}{*}{35 hari } & $40 \mathrm{ppm}$ & 0,312 & 66,879 \\
pemanasan & $60 \mathrm{ppm}$ & 0,3 & 68,153 \\
& $80 \mathrm{ppm}$ & 0,279 & 70,382 \\
\hline
\end{tabular}

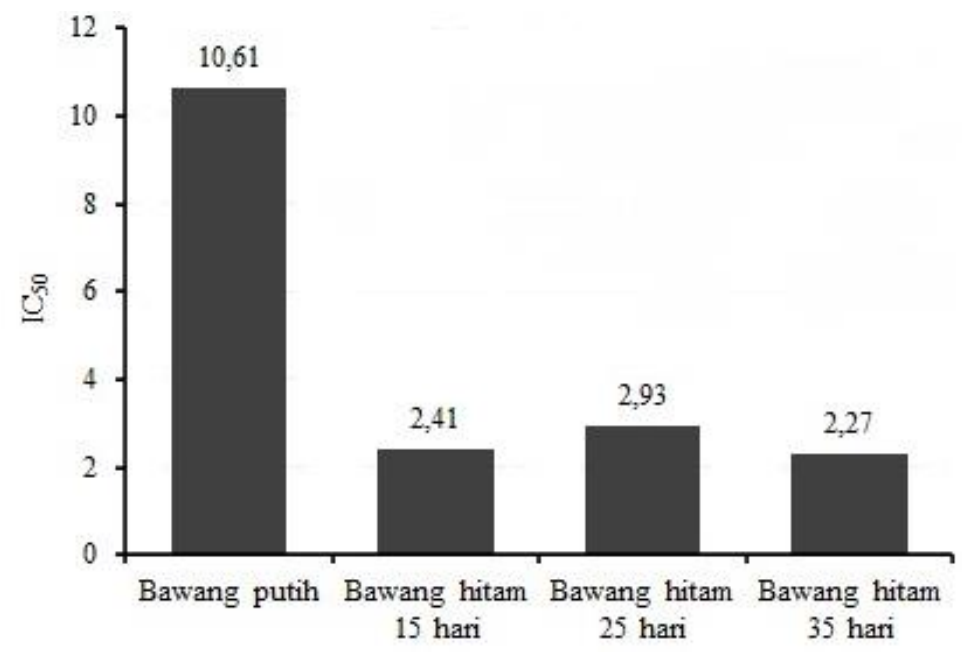

Gambar 2. Aktivitas antioksidan ekstrak bawang putih dan bawang hitam hasil beberapa lama pemanasan $(15,25$, dan 35 hari) 
Untuk melihat perbedaan penangkalan radikal bebas DPPH oleh senyawa aktif ekstrak bawang hitam atau persen inhibisi dari ketiga lama pemanasan (15 hari, 25 hari, dan 35 hari) dilakukan uji statistik anova one way. Sebelumnya dilakukan uji normalitas dan homogenitas untuk melihat apakah memenuhi syarat diuji anova one way. Didapatkan hasil uji normalitas ( $\mathrm{p}=0,908)$ dan uji homogenitas $(\mathrm{p}=0,156)$ dimana nilainya lebih besar dari $\alpha$ $(0,05)$ yang artinya memenuhi syarat pengujian anova one way. Dari uji anova one way didapatkan nilai $\mathrm{p}=0,004$ yang artinya terdapat perbedaan penangkalan radikal bebas atau persen inhibisi dari ketiga lama pemanasan (15 hari, 25 hari, dan 35 hari) dapat dilihat pada Tabel 5.

Selanjutnya untuk mengetahui kelompok lama pemanasan yang paling berpengaruh terhadap penangkalan radikal bebas dilanjutkan dengan uji post hoc (LSD). Dari hasil tersebut diperoleh perbedaan antara kelompok 35-15 hari $(\mathrm{p}=0,002)$ dan kelompok 35-15 hari $(\mathrm{p}=0,005)$. Lama pemanasan yang paling baik adalah adalah 35 hari dilihat dari nilai mean difference yang paling tinggi dapat dilihat pada Tabel 6 .

Tabel 5. Uji statistik penangkalan radikal bebas 2,2-diphenyl-1-picrylhydrazyl (DPPH) oleh senyawa aktif ekstrak bawang hitam

\begin{tabular}{lcc}
\hline \multicolumn{1}{c}{ Uji statistik } & Asymp.sig $(\mathrm{p})$ & Keterangan \\
\hline Normalitas & 0,908 & Signifikan \\
Homogenitas & 0,156 & Signifikan \\
Anova one way & 0,004 & Signifikan \\
\hline
\end{tabular}

Tabel 6. Perbedaan lama pemanasan yang paling berpengaruh terhadap persentase inhibisi

\begin{tabular}{ccc} 
Perlakuan & Mean difference & Asymp.sig $(\mathrm{p})$ \\
\hline 35 hari $*$ 15 hari & 20,753667 & 0,002 \\
35 hari $*$ 25 hari & 17,463000 & 0,005 \\
\hline
\end{tabular}

\section{PEMBAHASAN}

Bawang hitam diperoleh dengan cara memanaskan bawang putih pada suhu $70{ }^{\circ} \mathrm{C}$ selama 15, 25 dan 35 hari. Pemanasan bawang hitam antara $60-70{ }^{\circ} \mathrm{C}$ mampu meningkatkan kandungan gula reduksi. Pemanasan diatas suhu $70{ }^{\circ} \mathrm{C}$ menyebabkan rusaknya beberapa struktur gula reduksi yang ada pada bawang hitam, sedangkan apabila menggunakan suhu dibawah $60{ }^{\circ} \mathrm{C}$ proses pembuatan bawang hitam membutuhkan waktu yang sangat lama (Zhang, Li, Lu, Liu, \& Qiao, 2016). Bawang hitam memiliki aroma yang tidak terlalu menyengat jika dibandingkan dengan bawang putih segar. Hal ini karena perubahan senyawa alin menjadi senyawa turunannya seperti $S$ alylcystein (SAC). Senyawa alin merupakan senyawa yang menyebabkan aroma menyengat pada bawang putih. Dengan adanya perubahan senyawa alin menjadi SAC aroma dari bawang putih akan hilang. Kandungan SAC dari bawang hitam 4-8 kali lipat daripada bawang putih. Aroma bawang putih mulai hilang pada lama pemanasan 15 hari dan berubah menjadi aroma segar khas bawang hitam mulai hari ke25. Pada bawang hitam tingkat kadar air mengalami penurunan $34,3 \%$, kandungan protein meningkat $0,7 \%$, lemak meningkat $0,4 \%$, karbohidrat meningkat $18,3 \%$, kadar gula total meningkat $34,6 \%$, gula reduksi meningkat $24 \%, \mathrm{pH}$ menurun $3,3 \%$, kecerahan warna menurun $64,1 \%$, kemerahan meningkat $6,5 \%$, warna kuning menurun $30,5 \%$, kalori meningkat $89,1 \%$ dibandingkan bawang putih (Ryu \& Kang, 2017).

Proses pemanasan dalam pembuatan bawang hitam juga dapat memengaruhi perubahan warna. Perubahan warna bawang putih menjadi bawang hitam disebabkan terjadinya proses pencokelatan (browning) non-enzimatis. Proses pencokelatan nonenzimatis yang terjadi pada proses pemanasan bawang putih ini disebabkan reaksi Maillard. Reaksi Maillard melibatkan reaksi perubahan gula reduksi dan sejumlah asam amino. Mekanisme reaksi Maillard ada tiga tahap, tahap pertama adalah reaksi kondensasi antara gula reduksi dengan amina sedangkan warna 
bawang masih putih. Tahap kedua merupakan dehidrasi, fragmentasi gula, dan degradasi asam amino, pada tahap ini warna bawang menjadi cokelat muda. Tahap ketiga meliputi reaksi kondensasi aldehid-amina dan pembentukan senyawa Hydroxymethyl 2furfuraldehid yaitu senyawa yang menyebabkan warna cokelat pada makanan. Pada penelitian ini bawang hitam yang diperoleh dapat dilihat pada Tabel 1. Gula reduksi bawang hitam meningkat $24 \%$ daripada bawang putih segar (Ryu \& Kang, 2017).

Bawang hitam yang diperoleh dari proses pemanasan bawang putih diekstraksi untuk memperoleh kandungan senyawa aktif. Sebelum diekstraksi bawang hitam dihaluskan terlebih dahulu untuk memperkecil luas permukaan kontak dengan pelarut. Ekstraksi dilakukan dengan metode maserasi dengan pelarut metanol. Metanol mampu mengekstraksi senyawa yang bersifat polar dan semi polar karena tetapan dielektrik 80 . Tetapan dielektrik menunjukkan derajat kepolaran, semakin besar tetapan dielektrik maka semakin besar kepolaran pelarut tersebut, sehingga dapat dikatakan bahwa kepolaran dari pelarut metanol lebih rendah daripada pelarut air. Selanjutnya untuk mengetahui kandungan senyawa aktif dalam ekstrak bawang hitam dilakukan uji fitokimia. Uji fitokimia ekstrak bawang hitam meliputi uji alkaloid, tanin, saponin, sterol, dan flavonoid.

Uji senyawa alkaloid dilakukan dengan metode Wagner. Hasil positif alkaloid ditandai dengan terbentuknya endapan cokelat muda sampai kuning. Endapan tersebut dihasilkan dari reaksi antara kalium iodida dengan ekstrak. Ion logam $\mathrm{K}^{+}$akan membentuk ikatan kovalen koordinasi dengan nitrogen pada alkaloid, sehingga membentuk kompleks kalium-alkaloid yang dapat mengendap (Marliana et al., 2005). Ekstrak bawang hitam yang direaksikan dengan pereaksi Wagner tidak menghasilkan endapan sehingga tidak mengandung alkaloid. Dalam setiap ekstrak tidak selalu ditemukan senyawa aktif. Hal ini sesuai dengan penelitian yang dilakukan oleh (Kimura et al., 2017) yang menyatakan bahwa ekstrak bawang hitam banyak mengandung senyawa flavonoid, polifenol, dan negatif senyawa alkaloid.
Senyawa tanin merupakan salah satu turunan dari senyawa fenol. Jang et al. (2013) menyatakan bahwa bawang hitam mengandung senyawa aktif S-alylcystein (SAC), vitamin, asam fenolik dan senyawa flavanoid. Uji tanin menunjukkan hasil positif ditandai dengan terbentuknya endapan cokelat tua. Endapan terbentuk karena terjadi komplek $\mathrm{FeCl}_{3}$-tanin. Tanin merupakan senyawa polifenol yang banyak terdapat pada tanaman (Mukhriani, Nonci, \& Mumang, 2017). Tanin memiliki struktur gugus hidroksil (-OH) dan karboksil ($\mathrm{COOH})$. Gugus inilah yang diindikasi mampu digunakan sebagai penangkal radikal bebas. Total polifenol bawang hitam paling optimum pada saat lama pemanasan 28 hari yaitu sebesar 58,33 mg GAE/g (Choi et al., 2014).

Uji saponin menunjukkan hasil positif ditandai dengan terbentuknya busa. Saponin digolongkan ke dalam dua kelompok yaitu steroid dan triterpenoidal. Hal ini didukung dengan uji sterol yang menunjukkan hasil yang positif. Sterol merupkan senyawa lipid yang mempunyai struktur dasar yang sama dan derivat dari perhidrosiklopentanofenantrena. Meskipun pelarut yang digunakan adalah pelarut polar, namun mampu mengekstrak senyawa non polar, namun dimungkinkan dalam jumlah yang sedikit.

Uji positif flavonoid ditunjukkan dengan terjadinya perubahan warna larutan menjadi merah. Flavonoid merupakan senyawa metabolit sekunder yang banyak ditemukan di dalam jaringan tanaman. Flavonoid termasuk dalam golongan senyawa fenolik dengan memiliki gugus hidroksil -OH. Flavonoid dapat digunakan sebagai antioksidan dengan cara antara lain mendonorkan atom hidrogen di gugus - $\mathrm{OH}$, mengkelat logam, membentuk glukosida dan aglikon (Redha, 2010). Total flavonoid tertinggi diperoleh pada lama pemanasan 28 hari sebesar 16,26 mg RE/g. Proses pemanasan pada bawang hitam meningkatkan kandungan polifenol dengan cara menurunkan ester, glikosida, dan fraksi ikatan ester sehingga pembentukan fenol bebas meningkat (Choi et al., 2014). Flavonoid jenis quercetin meningkat $0,7(\mathrm{mg} / 100 \mathrm{~g})$, rutin meningkat 1.248 (mg/100 g) (Ryu \& Kang, 2017).

Aktivitas antioksidan ekstrak bawang ditentukan dengan metode serapan radikal 
DPPH (1,1-diphenyl-2-picylhydrazyl). DPPH merupakan senyawa radikal yang stabil, karena elektron akan mengalami delokalisasi diseluruh molekul sehingga terjadi dimerisasi yang menyebabkan terjadinya radikal bebas. Prinsip pengujian aktivitas antioksidan dengan metode DPPH adalah adanya donor atom hidrogen dari senyawa antioksidan ke DPPH radikal. DPPH ini berwarna ungu, karena delokalisasi elektron ditunjukkan oleh pita serapan pada panjang gelombang sekitar 520 nm, ketika dicampur dengan senyawa yang dapat mendonorkan atom hidrogen, terjadi peningkatan bentuk tereduksi dari DPPH, yaitu 1,1-diphenyl-2-picylhydrazyl yang mengakibatkan hilangnya warna ungu dan berubah menjadi terbentuk warna kuning pucat. Perubahan warna menyebabkan turunnya nilai absorbansi dari larutan. Penurunan nilai absorbansi disebabkan oleh tingginya konsentrasi senyawa aktif yang mampu menangkal radikal bebas DPPH. Selanjutnya dari perbedaan nilai absorbansi diperoleh nilai persen inhibisi. Persen inhibisi meningkat berarti penghambatan radikal bebas oleh sampel semakin bagus. Dari nilai persen inhibisi dan konsentrasi dibuat grafik regresi linier untuk mendapatkan nilai IC $_{50}$. Nilai IC $_{50}$ ekstrak bawang hitam dengan lama pemanasan 15 hari yaitu $2,41 \mu \mathrm{g} / \mathrm{mL}$; ekstrak bawang hitam dengan lama pemanasan 25 hari yaitu $2,93 \mu \mathrm{g} / \mathrm{mL}$; ekstrak bawang hitam dengan lama pemanasan 35 hari yaitu $2,27 \mu \mathrm{g} / \mathrm{mL}$. Ketiga ekstrak bawang hitam dengan variasi lama pemanasan memiliki nilai aktivitas antioksidan yang sangat kuat karena memiliki nilai $\mathrm{IC}_{50}<10 \quad \mathrm{ppm} \quad(\mu \mathrm{g} / \mathrm{mL})$. Aktivitas antioksidan bawang hitam lebih bagus dibandingkan dengan bawang putih dengan nilai IC50 10,61 (Prasonto, Riyanti, \& Gartika, 2017). Proses penangkalan radikal bebas DPPH oleh senyawa antioksidan seperti fenolik dan flavonoid dapat dilihat pada Gambar 3.

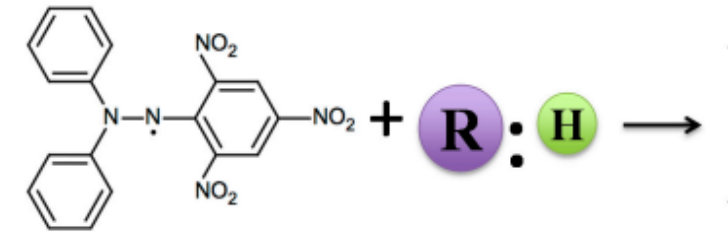

DPPH

Senyawa antioksidan

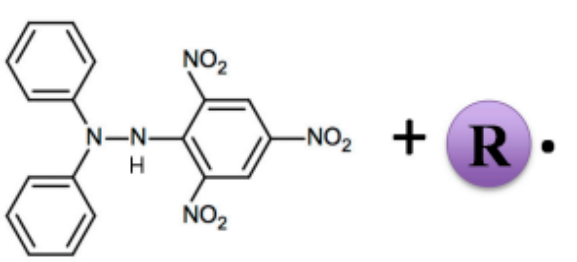

DPPH-H

Gambar 3. Penangkalan radikal bebas DPPH oleh senyawa antioksidan (Liang \& Kitts, 2014)

Mekanisme reaksi penangkalan radikal bebas DPPH oleh senyawa antioksidan (R:H) yang ditunjukkan pada Gambar 3, yaitu senyawa antioksidan (R:H) mendonorkan satu elektron pada atom hidrogen ke radikal bebas DPPH. Dalam pengujian DPPH, elektron radikal menunjukkan penyerapan yang kuat pada panjang gelombang $519 \mathrm{~nm}$, dan kehilangan penyerapan begitu elektron radikal dipasangkan oleh hidrogen atau antioksidan yang menyumbangkan elektronnya (Liang \& Kitts, 2014). Satu elektron dari atom hidrogen dari senyawa antioksidan akan berikatan dengan satu elektron bebas nitrogen pada DPPH, sehingga struktur dari DPPH akan stabil membentuk senyawa DPPH-H. Sedangkan satu elektron bebas dari senyawa antioksidan ( $\mathrm{R} \cdot$ ) yang telah kehilangan elektron atom hidrogen akan mudah terdegradasi (Prakash, Rigelhoft, \& Miller, 2001).
Uji aktivitas fungsi biologis menunjukkan hasil bahwa potensi antioksidan pada bawang hitam meningkat drastis dengan aktivitasnya mencapai 25 kali lipat lebih banyak dibandingkan dengan bawang putih segar. Bawang hitam yang diperoleh dari Jepang menunjukan $\mathrm{IC}_{50}$ 4,1 di bandingkan dengan ketika masih berupa bawang putih segar dengan nilai $\mathrm{IC}_{50}$ 114,9. Begitu pula bawang hitam dari Cina memiliki nilai IC50 7,3 dibandingkan dengan sebelum terjadi pemanasan dengan nilai IC $_{50}$ 88,5 (Sasaki et al., 2007). Peningkatan aktivitas antioksidan dari bawang hitam disebabkan meningkat pula konsentrasi kandungan senyawa aktif serta terbentunya senyawa baru akibat reaksi Maillard. Senyawa aktif yang meningkat adalah flavonoid dan polifenol, sedangkan senyawa baru yang terbentuk adalah Salylcystein (SAC) (Ryu \& Kang, 2017). 
Ekstrak bawang hitam dengan variasi pemanasan 15,25 , dan 35 hari memiliki aktivitas antioksidan yang kuat karena mengandung senyawa aktif flavonoid, tanin, saponin, dan sterol. Senyawa tanin, saponin, dan sterol pada strukturnya mengandung gugus hidroksil yang dapat mendonorkan atom hidrogen pada radikal bebas. Aktivitas antioksidan senyawa polifenol dapat dihasilkan pada reaksi netralisasi radikal bebas atau penghentian reaksi berantai yang terjadi akibat radikal bebas. Polifenol merupakan senyawa pereduksi yang dapat menghambat banyak reaksi oksidasi. Aktivitas peredaman radikal bebas senyawa fenol dipengaruhi oleh jumlah dan posisi hidrogen fenolik dalam molekulnya. Semakin banyak jumlah gugus hidroksil yang dimiliki oleh senyawa fenol, maka semakin besar aktivitas antioksidan yang dihasilkan. Salah satu jenis flavonoid yang memiliki aktivitas penangkalan kuat terhadap radikal bebas adalah senyawa kuersetin. Senyawa kuersetin juga ditemukan dalam bawang hitam (Ryu \& Kang, 2017). Kuersetin memiliki gugus hidroksil dan dapat membentuk radikal baru, radikal kuersetin dapat distabilisasi dengan adanya gugus ortohidroksi fenolik pada cincin B dan gugus fenolik pada cincin A (Irianti, Puspitasari, Machwiyyah, \& Rabbani, 2016). Perbedaan nilai IC50 setiap variasi lama pemanasan tidak signifikan pengaruh terhadap nilai $\mathrm{IC}_{50}$.

Perbedaan penangkalan radikal bebas DPPH oleh senyawa antioksidan ekstrak bawang hitam atau persen inhibisi dari ke tiga lama pemanasan (15 hari, 25 hari, dan 35 hari) dapat diketahui dari uji statistik (Anova). Dari ketiga lama pemanasan bawang hitam memberikan hasil yang signifikan terhadap penangkalan radikal bebas. Lama yang paling bagus dari proses penangkalan radikal bebas DPPH adalah lama pemanasan 35 hari dapat dilihat pada Tabel 5. Hal ini sesuai dengan data yang diperoleh dari nilai IC50. Menurut nilai IC50 lama pemanasan selama 35 hari memiliki nilai $\mathrm{IC}_{50}$ yang paling kecil diantara ketiga lama pemanasan yaitu sebesar 2,27 ppm. Semakin kecil nilai $\mathrm{IC}_{50}$ suatu ekstrak maka kemampuan penangkalan radikal bebas oleh senyawa aktif yang ada dalam suatu ekstrak dapat berjalan optimum. Pada lama pemanasan selama 35 hari diperoleh kadar flavonoid lebih banyak dibandingkan dengan lama pemanasan 15 dan 25 hari, dilihat dari uji fitokimia yang menunjukkan perubahan warna larutan yang lebih pekat. Reaktivitas hidroksi yang tinggi pada kelompok senyawa flavonoid mampu menstabilkan radikal bebas DPPH (Nijveldt et al., 2001).

\section{SIMPULAN}

Ekstrak bawang hitam dengan variasi lama pemanasan 15,25 , dan 35 hari dengan pelarut metanol memiliki aktivitas antioksidan yang sangat kuat dengan nilai IC50 masingmasing adalah 15 hari 2,41 ppm; 25 hari 2,93 ppm; dan 35 hari 2,27 ppm. Ekstrak bawang hitam berpotensi sebagai antioksidan yang kuat, karena mengandung senyawa aktif flavonoid, tanin, saponin, dan sterol yang mampu menstabilkan radikal bebas dengan mendonorkan senyawa hidroksil. Lama pemanasan yang paling optimum dalam penangkalan radikal bebas adalah ekstrak bawang hitam dalam lama pemanasan 35 hari.

\section{REFERENSI}

Amagase, H. (2006). Clarifying the real bioactive constituents of garlic. The Journal of Nutrition, 136(3), 716S-725S. doi: 10.1093/jn/136.3.716S.

Angeles, T. M. M., Jesus, P. A., Rafael, M. R., \& Tania, M. A. (2016). Evolution of some physicochemical and antioxidant properties of black garlic whole bulbs and peeled cloves. Food Chemistry, 199, 135-139.

doi: 10.1016/j.foodchem.2015.11.128.

Bae, S. E., Cho, S. Y., Won, Y. D., Lee, S. H., \& Park, H. J. (2014). Changes in S-allyl cysteine contents and physicochemical properties of black garlic during heat treatment. LWT-Food Science and Technology, 55(1), 397-402. doi: 10.1016/j.lwt.2013.05.006.

Chen, Y.-C., Kao, T.-H., Tseng, C.-Y., Chang, W.-T., \& Hsu, C.-L. (2014). Methanolic extract of black garlic ameliorates dietinduced obesity via regulating adipogenesis, adipokine biosynthesis, and lipolysis. Journal of Functional Foods, 9, 98-108. doi: 10.1016/j.jff.2014.04.014. 
Choi, J.-G., Mun, S.-H., Chahar, H. S., Bharaj, P., Kang, O.-H., Kim, S.-G., ... Kwon, D.-Y. (2014). Methyl gallate from Galla rhois successfully controls clinical isolates of Salmonella infection in both in vitro and in vivo systems. PLOS ONE, 9(7), e102697. doi: 10.1371/journal.pone.0102697.

Ghiselli, A., Nardini, M., Baldi, A., \& Scaccini, C. (1998). Antioxidant activity of different phenolic fractions separated from an Italian red wine. Journal of Agricultural and Food Chemistry, 46(2), 361-367. doi: 10.1021/jf970486b.

Halliwell, B., \& Gutteridge, J. M. C. (2015). Free radicals in biology and medicine (fifth edition). United Kingdom: Oxford University Press.

Hernawan, U. E., \& Setyawan, A. D. (2003). Review: Senyawa organosulfur bawang putih (Allium sativum L.) dan aktivitas biologinya. Biofarmasi, 1(2), 65-76.

Irianti, T., Puspitasari, A., Machwiyyah, L., \& Rabbani, H. R. (2016). The activity of radical scavenging of 2,2-diphenyl-1pycrilhydrazil (DPPH) by ethanolic extracts of mengkudu leaves (Morinda citrifolia L.), brotowali stem (Tinospora crispa L.), its water fraction and its hydrolized fraction. Majalah Obat Tradisional, 20(3), 140-148. doi: $10.22146 /$ tradmedj.8850.

Jang, J.-E., Kim, S.-W., Kim, S.-Y., Kim, J.M., Park, M.-H., Yoon, J.-H., ... Yoon, J.-S. (2013). Religiosity, depression, and quality of life in Korean patients with breast cancer: A 1-year prospective longitudinal study. Psycho-Oncology, 22(4), 922-929. doi: 10.1002/pon.3083.

Kementerian Kesehatan RI. (2015). Situasi penyakit kanker. Jakarta: Pusat Data Dan Informasi Keementerian Kesehatan Republik Indonesia.

Kimura, S., Tung, Y.-C., Pan, M.-H., Su, N.W., Lai, Y.-J., \& Cheng, K.-C. (2017). Black garlic: A critical review of its production, bioactivity, and application. Journal of Food and Drug Analysis, 25(1), 62-70. doi: 10.1016/j.jfda.2016.11.003.
Liang, N., \& Kitts, D. D. (2014). Antioxidant property of coffee components: Assessment of methods that define mechanisms of action. Molecules, 19(11), 19180-19208. doi: 10.3390/molecules191119180.

Lu, X., Li, N., Qiao, X., Qiu, Z., \& Liu, P. (2017). Composition analysis and antioxidant properties of black garlic extract. Journal of Food and Drug Analysis, 25(2), 340-349. doi: 10.1016/j.jfda.2016.05.011.

Marliana, S. D., Suryanti, V., \& Suyono. (2005). Skrining Fitokimia dan analisis kromatografi lapis tipis komponen kimia buah labu siam (Sechium edule Jacq. Swartz.) dalam ekstrak etanol. Biofarmasi, 3(1), 26-31.

Mukhriani, M., Nonci, F. Y., \& Mumang, M. (2017). Penetapan kadar tanin total ekstrak biji jintan hitam (Nigella sativa) secara spektrofotometri uv-vis. Jurnal Farmasi UIN Alauddin Makassar, 2(4), 154-158.

Nijveldt, R. J., van Nood, E., van Hoorn, D. E., Boelens, P. G., van Norren, K., \& van Leeuwen, P. A. (2001). Flavonoids: A review of probable mechanisms of action and potential applications. The American Journal of Clinical Nutrition, 74(4), 418425. doi: 10.1093/ajcn/74.4.418.

Prakash, A., Rigelhoft, F., \& Miller, E. (2001). Antioxidant activity. Medallion Laboratories-Analytical Progress, 19(2), 1-4.

Prasonto, D., Riyanti, E., \& Gartika, M. (2017). Uji aktivitas antioksidan ekstrak bawang putih (Allium sativum). Odonto: Dental Journal, 4(2), 122-128. doi: 10.30659/odj.4.2.122-128.

Redha, A. (2010). Flavonoid: Struktur, sifat antioksidatif dan peranannya dalam sistem biologis. Jurnal Belian, 9(2), 196202.

Rukmana, R. (1995). Budidaya bawang putih. Yogyakarta: Kanisius.

Ryu, J. H., \& Kang, D. (2017). Physicochemical properties, biological activity, health benefits, and general limitations of aged black garlic: A review. Molecules, 22(6), 919-932. doi: 10.3390/molecules22060919. 
Sasaki, J., Lu, C., Machiya, E., Tanahashi, M., \& Hamada, K. (2007). Processed black garlic (Allium sativum) extracts enhance anti-tumor potency against mouse tumors. Medical and Aromatic Journal of Plant Science and Biotechnology, 1, 278-281.

Sengin, E. L. (1992). Perbanyakan mikro pada tanaman bawang putih (Allium sativum L.) (Disertasi doktoral, Institute Pertanian Bogor, Bogor, Indonesia). Retrieved from http://repository.ipb.ac.id/handle/123456 789/23136

Song, K., \& Milner, J. A. (2001). The influence of heating on the anticancer properties of garlic. The Journal of Nutrition, 131(3), 1054S-1057S. doi: 10.1093/jn/131.3.1054S.

Teow, C. C., Truong, V.-D., McFeeters, R. F., Thompson, R. L., Pecota, K. V., \& Yencho, G. C. (2007). Antioxidant activities, phenolic and $\beta$-carotene contents of sweet potato genotypes with varying flesh colours. Food Chemistry, 103(3), 829-838. doi: 10.1016/j.foodchem.2006.09.033.
Ulfa, E. U., \& Hidayat, M. A. (2007). Uji aktivitas antioksidan ekstrak buah naga (Hylocereus undatus (Haw.) Britt. \& Rose). Jurnal Ilmu Dasar, 8(1), 83-90.

Velázquez, E., Tournier, H. A., Mordujovich de Buschiazzo, P., Saavedra, G., \& Schinella, G. R. (2003). Antioxidant activity of Paraguayan plant extracts. Fitoterapia, 74(1-2), 91-97. doi: 10.1016/s0367-326x(02)00293-9.

Wang, D., Feng, Y., Liu, J., Yan, J., Wang, M., Sasaki, J., \& Lu, C. (2010). Black garlic (Allium sativum) extracts enhance the immune system. Medical and Aromatic Journal of Plant Science and Biotechnology, 4(1), 37-40.

Zhang, X., Li, N., Lu, X., Liu, P., \& Qiao, X. (2016). Effects of temperature on the quality of black garlic. Journal of the Science of Food and Agriculture, 96(7), 2366-2372. doi: 10.1002/jsfa.7351. 